\title{
TRYPANOSOMA CRUZI : Attenuation of virulence by culture in tissues ${ }^{1}$.
}

\author{
S. URDANETA-MORALES*
}

\begin{abstract}
SUMMARY. Trypomastigotes of the 'Brazil' strain of Trypanosoma cruzi were cultured in Vero and fish (Pimephales promelas) cells at 30 and $37 \mathrm{C}$. Those harvested from $37 \mathrm{C}$ Vero cell cultures killed all inoculated $\mathrm{C}_{3} \mathrm{H}$ mice no matter how long the cultures had been maintained. Those harvested from 120-day $30 \mathrm{C}$ Vero and fish cultures killed only 1 out of 10 mice each, indicating attenuation of virulence. When the surviving mice were later challenged with Vero-cultured trypomastigotes known to be lethal to controls, only 2 of the 18 animals developed even light parasitaemias, indicating previous immunization by the attenuated parasites. Varying the number of attenuated trypomastigotes cultured at $30 \mathrm{C}$ for 30 days at most delayed the rise of parasitaemia. Possible mechanisms of these phenomena are discussed.
\end{abstract}

\section{Trypanosoma cruzi : atténuation de la virulence en culture de tissus.}

RÉSUMÉ. Des trypomastigotes de la souche "Brazil » de Trypanosoma cruzi ont été cultivés sur cellules Vero et de poisson (Pimephales promelas) à 30 et $370 \mathrm{C}$. Ceux récoltés des cultures Vero, à $37^{\circ} \mathrm{C}$, ont tué toutes les souris $\mathrm{C}_{3} \mathrm{H}$ inoculées, indépendamment de la durée des cultures. Ceux récoltés après 120 jours à $30^{\circ} \mathrm{C}$, de cultures Vero et de poisson ont tué seulement 1 souris sur 10 dans chaque cas, indiquant une atténuation de la virulence. Quand les souris survivantes ont été soumises plus tard aux trypomastigotes cultivés en Vero, connu pour être léthal aux contrôles, 2 seulement des 18 survivantes ont présenté de légères parasitémies, révélant une immunisation préalable par les parasites atténués. En variant le nombre des trypomastigotes atténués, cultivés à $30^{\circ} \mathrm{C}$ pendant 30 jours, la croissance de la parasitémie a été tout au plus retardée. Des mécanismes possibles de ces phénomènes sont discutés.

\section{Introduction}

Since control of the vectors of Chagas' disease is difficult, and since chemotherapy against Trypanosoma cruzi is as yet ineffective (Gutteridge, 1976), efforts toward immunization are being made ; it appears that living flagellates are the most effective antigens (Menezes, 1976).

The present work describes the protective effects of a strain of $T$. cruzi attenuated by culture in cells from a homoiotherm and a poikilotherm (monkey and fish).

I. The present work was undertaken in partial fulfillment of the $\mathrm{Ph}$. D. thesis, University of Georgia, Athens, Georgia, USA, I979.

* Instituto de Zoologia Tropical, Facultad de Ciencias, Universidad Central de Venezuela, Apartado 47058, Los Chaguaramos 1041-A, Caracas, Venezuela.

Accepté le 24 août 1982 . 


\section{Materials and methods}

Parasite : the 'Brazil' strain of T. cruzi (Roberson et al., 1973) maintained by i.p. blood inoculation at 15-day intervals into $\mathrm{CF}_{1}$ female mice, 3-4 weeks old (Carworth Farms, Portage, Mich., USA).

Cell lines: Vero fibroblasts and epithelial cells of the fish Pimephales promelas (both from American Type Culture Coll., Rockville, Ma., USA). They were cultured in $75 \mathrm{~cm}^{2}$ Falcon flasks, at 37 and $30 \mathrm{C}$ respectively, by the technic of Hanson et al. (1976).

Infection of tissue cultures : week-old monolayers of Vero cells were inoculated with mouse blood containing $1 \times 10^{6}$ trypomastigotes, and incubated at $37 \mathrm{C}$. After $24 \mathrm{hr}$, the blood was discarded, the cultures washed several times with fresh medium, and then maintained at $37 \mathrm{C}$, with medium changed thrice weekly.

After 2 weeks, the parasites in the pooled supernatants of the flasks were concentrated by centrifuging under refrigeration at $8,000 \mathrm{~g}$ for $10 \mathrm{~min}$, and were then washed 3 times with fresh medium in the same way.

Of these parasites, $1 \times 10^{6}$ were seeded into Falcon flasks containing week-old cell monolayers, 4 each with Vero cells and fish cells. Two flasks of each type were incubated at $37 \mathrm{C}$ and 2 at $30 \mathrm{C}$. Medium was changed 3 times weekly, and the relative numbers of amastigotes and trypomastigotes present was determined from thick Giemsa-stained smears by the technic of Hanson \& Roberson (1974). Cultures were maintained until phase microscopy showed signs of deterioration. The cultures were lavishly washed with fresh medium at each change to inhibit extra-cellular development of $T$. cruzi to the amastigote, and later, epimastigote stage (Kamura et al., 1978).

For long-term study of $T$. cruzi in culture, a further 8 flasks were inoculated and maintained exactly as above. Every 2 weeks, the parasites were harvested as above, and a new set of cultures inoculated with $1 \times 10^{6}$ trypomastigotes each from the preceding culture.

Infections of mice with cultured trypomastigotes : each of the following experimental groups consisted of 10 female $\mathrm{C}_{3} \mathrm{H}$ mice, 4-5 weeks old (Flow Lab., Dublin, Va., USA).

Each i.p. inoculum contained $5 \times 10^{4}$ trypomastigotes that were harvested as follows :

1 - from Vero cell culture, $30 \mathrm{C}, 45$ days in culture ;

2 - from Vero cell culture, $37 \mathrm{C}, 45$ days in culture ;

3 - controls - from $\mathrm{CF}_{1}$ mouse with high parasitaemia ;

4 - from Vero cell culture, $30 \mathrm{C}, 120$ days in culture ;

5 - from fish cell culture, $30 \mathrm{C}, 120$ days in culture ;

6 - controls - from Vero cell culture, 37 C, 300 days in culture.

Thick Giemsa-stained smears of tail blood from each mouse were made beginning 3 days postinfection, and 3 times weekly thereafter for evaluation of the parasitaemia, continuing until it disappeared or the animal died. 
Test of acquired immunity : the surviving mice from groups 1,4 and 5 were challenged by i.p. inoculation of $5 \times 10^{4}$ parasites harvested from the Vero $37 \mathrm{C}$ 10 -month culture. Group 1 was challenged 2 months after disappearance of parasitaemia ( 3 months postinfection). Groups 4 and 5 were challenged 3 months after disappearance of the parasitaemia (5 months postinfection). A control group of 10 mice was inoculated in the same way.

Test of virulence attenuation : 6 groups of mice were inoculated with $5 \times 10^{4}$, $5 \times 10^{3}$, or $5 \times 10$ trypomastigotes harvested from Vero or fish cell cultures maintained at $30 \mathrm{C}$ for 30 days, in order to evaluate the attenuation of the strain and the effect of the size of the inoculum. A control group was inoculated with 2-month $37 \mathrm{C}$ Vero cell-cultured parasites. The course of parasitaemia and mortality was recorded for each animal.

\section{Results}

Cultures: T. cruzi blood flagellates readily infect and develop within monolayers of Vero cells at $37 \mathrm{C}$. An inoculum of $1 \times 10^{6}$ parasites/flask will produce $3-5 \times 10^{6}$ trypomastigotes $/ \mathrm{ml}$ medium in about 2 weeks.

In fish cell cultures at $30 \mathrm{C}$. formation of extracellular trypomastigotes and amastigotes was inhibited ( $f$ g. 1).

At $37 \mathrm{C}$, fish cell cultures could not be long maintained ; the optimal temperatures for these cultures is 30-34 C (Wolf and Quimby, 1976).

At $30 \mathrm{C}$, there was a progressive diminution of trypomastigotes in long-maintained cultures of both types of cell, while Vero cells at $37 \mathrm{C}$ continued to develop large numbers of trypomastigotes for up to 8 months of continuing transfers (fig. 2).

Mouse infections with subcultures from tissues : culture of $T$. cruzi in Vero cells at $37 \mathrm{C}$ for 45 days did not diminish its virulence (fig. $3 \mathrm{~A}$ ). Parasitaemias of an average $15.5 \times 10^{6} / \mathrm{ml}$ blood were reached at 25 days post-infection, and all mice died within 2-4 weeks.

Culture in Vero cells at $30 \mathrm{C}$ for 45 days had a strong effect on parasitaemia and mortality. The peak of parasitaemia was delayed to the 4 th week. One mouse died 40 days postinfection, and the other 9 survived to become chronic cases. All controls died 3-4 weeks post-infection, showing average parasitaemias of $13.6 \times 10^{6} / \mathrm{ml}$ blood 24 days postinfection ( fig. $3 \mathrm{~A}$ ).

Culture in Vero cells at $37 \mathrm{C}$ did not diminish virulence even after 10 months' culture. All mice infected from this culture died 3-4 weeks postinfection with peak parasitaemias of $15.8 \times 10^{6} / \mathrm{ml}$ blood ( fig. $3 \mathrm{~B}$ ).

The virulence of parasites cultured for 4 months at $30 \mathrm{C}$ was even lower for both types of cell culture than those cultured for 45 days. The highest parasitaemias seen were $78 \times 10^{4} / \mathrm{ml}$ for Vero cells, and, $53.5 \times 10^{4} / \mathrm{ml}$ for fish cells, both at 5 weeks postinfection; all animals infected with $37 \mathrm{C}$ Vero cell parasites had died by this time (fig. $3 \mathrm{~B}$ ). One mouse of each group had died 8 weeks after inoculation, and one animal infected from fish cells showed no parasitaemia. All mice showed growth and behavior similar to non-infected mice for the 2 months that they were observed. 
(A)

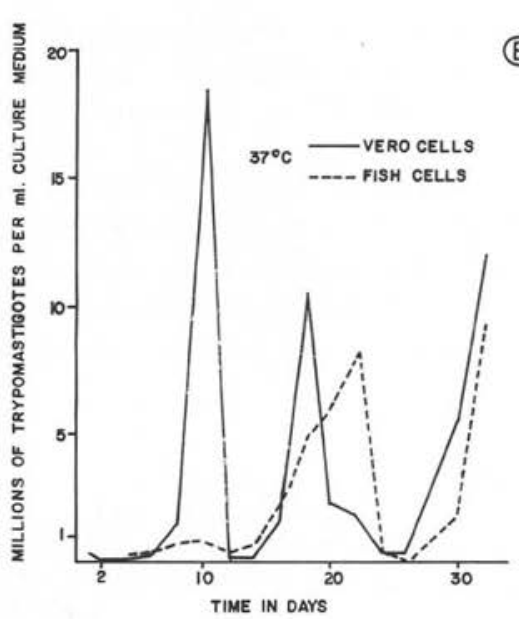

(C)

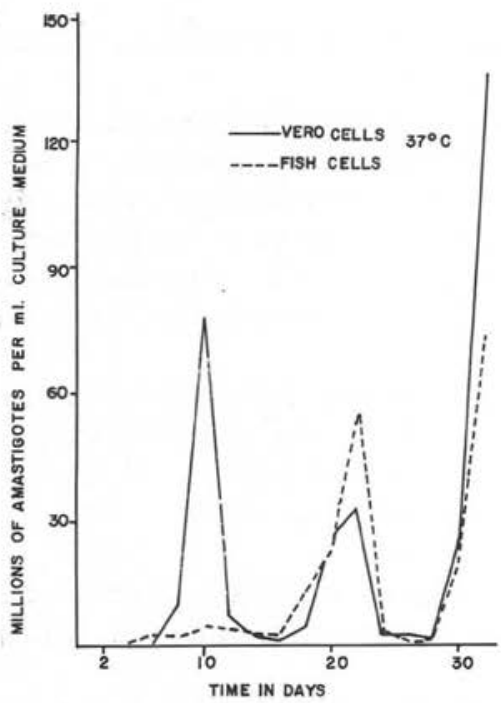

(B)

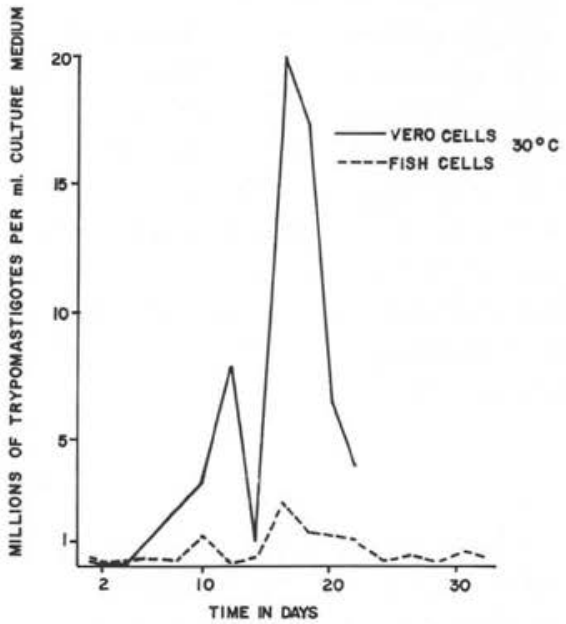

(D)

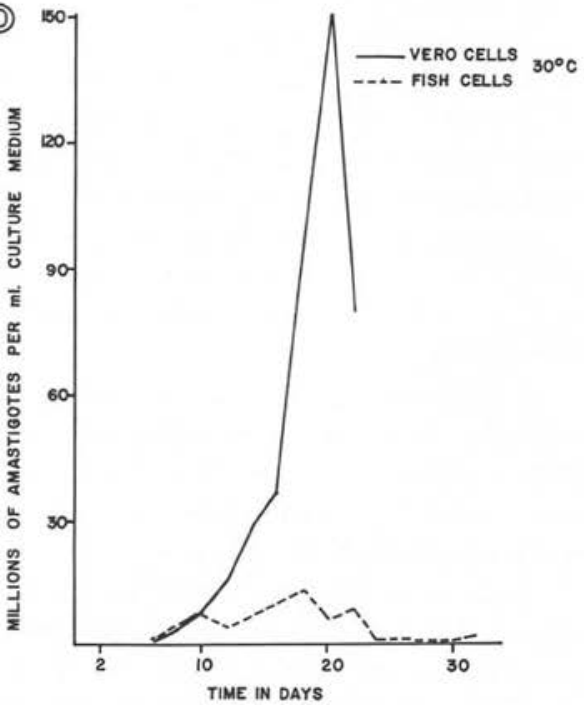

FIG. 1. - Extracellular stages of $T$. cruzi from Vero and fish cell cultures in Falcon flasks through 30 days of incubation at 30 and $37 \mathrm{C}$.

A) Trypomastigotes at $37 \mathrm{C}$; B) Trypomastigotes at $30 \mathrm{C}$; C) Amastigotes at $37 \mathrm{C}$; D) Amastigotes at $30 \mathrm{C}$. 

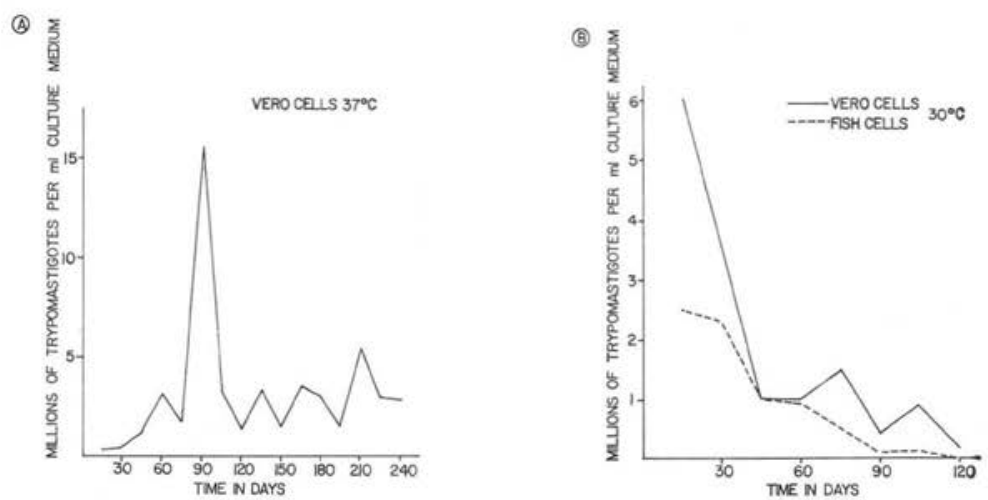

FIG. 2. - Extracellular trypomastigotes of T. cruzi from Vero and fish cell cultures in Falcon flasks successively transferred through a long period of time at 30 and $37 \mathrm{C}$.

(4)

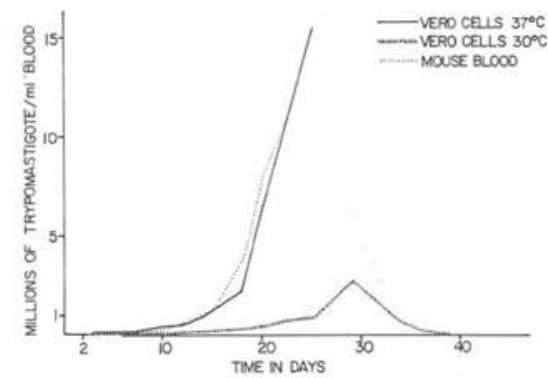

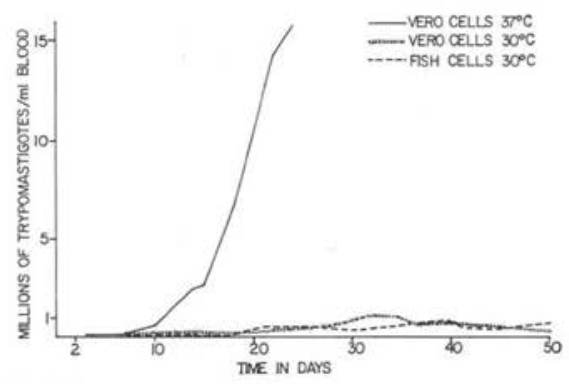

FIg. 3. - A) Parasitaemias in $\mathrm{C}_{3} \mathrm{H}$ mice inoculated with $5 \times 10^{4}$ trypomastigotes of $T$. cruzi from Vero cell cultures maintained for 45 days at 30 and $37 \mathrm{C}$. (Controls - blood trypomastigotes from $\mathrm{CF}_{1}$ mice.)

B) Parasitaemias in $\mathrm{C}_{2} \mathrm{H}$ mice inoculated with $5 \times \mathrm{IO}_{4}^{4}$ trypomastigotes of $T$. cruzi from Vero and fish cell cultures maintained for 4 months at $30 \mathrm{C}$. (Controls - trypomastigotes from 37 C Vero cell culture.)

There was no clear correlation between the size of the inoculum and the level of parasitaemia, except that the smallest inoculum tended to delay the rise of the parasitaemia ( fig. 4).

Inocula of parasites from fish cells cultured 30 days at $30 \mathrm{C}$ produced the lowest parasitaemias for all 3 dilutions ( $f i g$. 4). Vero cell parasites, 30 or $37 \mathrm{C}$, killed all mice within 35 days at all dilutions, so that 30 days' incubation at $30 \mathrm{C}$ did not significantly diminish virulence.

Challenge of immunity of surviving animals : none of the 9 mice surviving initial inoculation of $30 \mathrm{C}$ Vero cell parasites incubated 45 days showed parasitaemia after the challenge. 
(A)

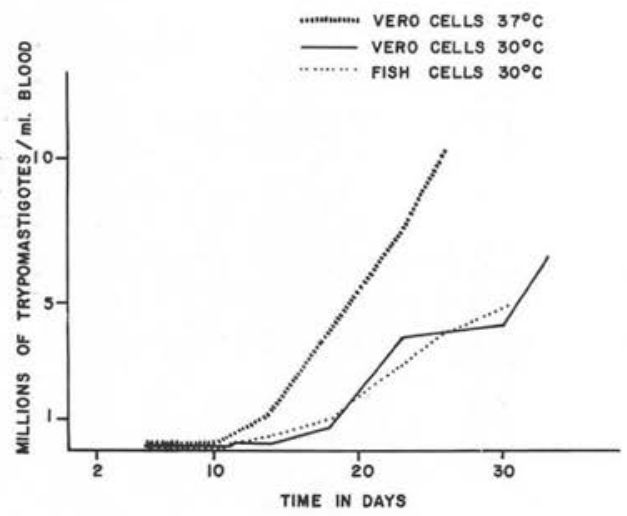

(B)

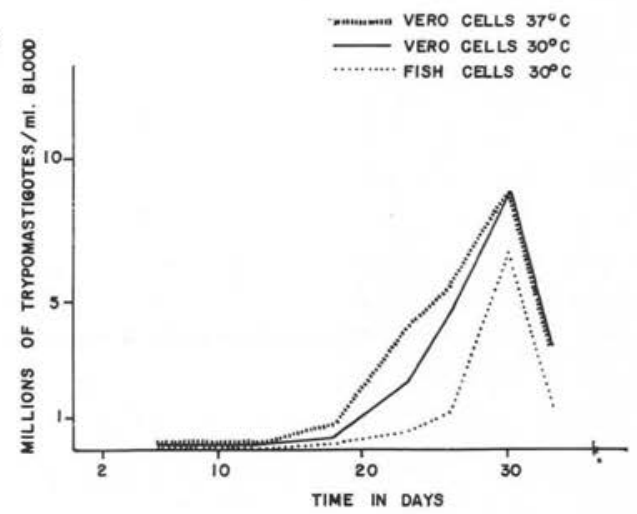

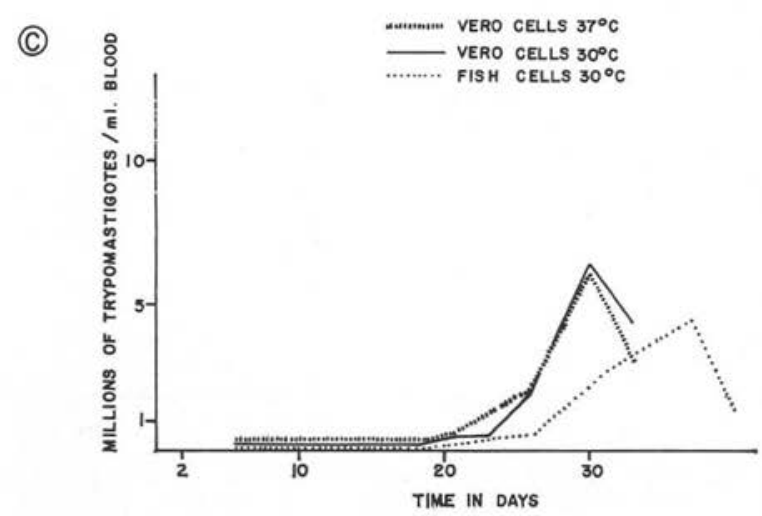

FIG. 4. - Parasitaemias in $\mathrm{C}_{3} \mathrm{H}$ mice inoculated with trypomastigotes of $T$. cruzi from Vero cell culture maintained for 60 days at $37 \mathrm{C}$, and from Vero and fish cell cultures maintained 30 days at $30 \mathrm{C}$.

A) $5 \times 10^{4}$ trypomastigotes/mouse ; B) $5 \times 10^{3}$ trypomastigotes/mouse ; C) $5 \times 10$ trypomastigotes/mouse.

One mouse from each group of survivors which had been inoculated originally from either type of cell culture maintained 4 months at $30 \mathrm{C}$ showed a light and fluctuating parasitaemia, never higher than $3-4 \times 10^{4} / \mathrm{ml}$ blood. The only mouse dying after challenge was that one which had showed no parasitaemia after being inoculated with $30 \mathrm{C}$ fish cell culture parasites. All controls infected with $37 \mathrm{C}$ Vero cell parasites died 3-4 weeks postinfection with the usual high parasitaemias. All the challenged animals grew and behaved similarly to non-infected mice during 7 months' observation, with no more deaths. 


\section{Discussion}

The infectivity and virulence of $T$. cruzi can be reduced by serial culture in liquid media (Menezes, 1968).

The present work reports attenuation of virulence by serial culture in Vero and fish cells at $30 \mathrm{C}$, demonstrated by i.p. inoculation of the cultured trypomastigotes into homozygotic $\mathrm{C}_{3} \mathrm{H}$ mice. This mouse strain is so susceptible to the 'Brazil' strain of $T$. cruzi that inoculation of only 10 parasites kills $100 \%$ of the animals (Hanson, 1977).

Pizzi (1961) considered the attenuation of cultured strains of T. cruzi as being due to the decreasing numbers of trypomastigotes in the culture medium ; however, Bice and Zeledon (1970) and Chiari (1974), on inoculating mice with equivalent numbers of metacyclic forms, were able to observe correlations between virulence and time of incubation. Rosenberg et al. (1969) reported that blood forms were much more infective than equal numbers of cultured trypomastigotes.

Temperature can be important in changing the virulence of intracellular parasites. Low incubation temperatures correlated with inhibition of growth of $T$. cruzi in cell culture has been demonstrated by Dvorak and Poore (1974) and by Bertelli et al. (1977). It may be that these conditions have led to a selection among the parasite population, the survivors being less virulent. Also, the changes in isoenzyme patterns of the parasite, reported by Romanha et al. (1979) in T. cruzi under prolonged culture might be related to changes in virulence ; in our experiments, these changes would have been greatest in fish cell culture at $30 \mathrm{C}$.

The low parasitaemias induced by infections of parasites incubated at $30 \mathrm{C}$ were sufficient to give a high degree of protection against infection by homologous virulent material. In our experiments, 24 of the 27 surviving animals did not develop parasitaemias when reinfected 3-5 months after the original infection. The only mouse dying after reinfection had failed to develop parasitaemia from the original infection. This emphasizes the importance of obtaining light infections by inoculation of attenuated parasites, which, together with completion of the intracellular life cycle, can stimulate immune protection in the host (Menezes, 1970).

The relation between size of inoculum and pathogenicity has been emphasized (Silva and Nussenzweig, 1953) and minimized (Mazzotti, 1940). Phillips (1960) has demonstrated that the relation holds for some strains but not for others ; some causing pathology according to the number of parasites inoculated, and others being lethal no matter the size of the inoculum. The 'Brazil' strain is one of the latter ; nearly all mice infected with virulent parasites of this strain in our experiments died within 5 weeks, independent of the number of parasites inoculated.

Acknowledgements. The author wishes especially to thank Dr. R. B. McGhee for his constant help and counsel during the work ; the Consejo de Desarrollo Cientifico y Humanistico de la Universidad Central de Venezuela for financial aid ; and Mr. Ian McLure for the English translation. 


\section{REFERENCES}

Bertelli M. S. M., Golgher R. R., Brener Z. : Intraspecific variation in Trypanosoma cruzi : Effect of temperature on the intracellular differentiation in tissue culture. $J$. Parasitol., I977, $63,434-437$.

Bice D. E., ZELEDon R. : Comparison of infectivity of strains of Trypanosoma cruzi. J. Parasitol., I970, s6, 663-670.

CHIARI E. : Infectivity of Trypanosoma cruzi metacyclic trypomastigotes from cultures kept in laboratory for different periods of time. Rev. Inst. Med. trop. (Sao Paulo), 1974, I6, 6I-67.

DvorAK J. A., POORE C. M. : Trypanosoma cruzi : Interaction with vertebrate cells in vitro. IV. Environmental temperature effects. Exp. Parasitol., 1974, 36, I 50-I 57.

GutTERIDGE W. E. : Experimental chemotherapy of Chagas' Disease. In : American Trypanosomiasis Research, W.H.O. Scient. Pub. No 3 I 8, 1976, Washington, D.C., USA, 4 Io p.

Hanson W. L. : Immune response and mechanisms of resistance in Trypanosoma cruzi. In : Chagas' Disease, P.A.H.O. Scient. Pub. No 347 , 1977, Washington, D.C., 387 p.

Hanson W. L., Chapman W. L., Waits V. B. : Immunization of mice with irradiated Trypanosoma cruzi grown in cell culture : relation of numbers of parasites, immunizing injections, and route of immunization to resistance. Int. J. Parasitol., 1976, 6, 34I-347.

Hanson W. L., Roberson E. L. : Density of parasites in various organs and the relation to numbers of trypomastigotes in the blood during acute infections of Trypanosoma cruzi in mice. J. Protozool., 1974, 21, 512-517.

KrmuRA E., LAY W. H., FERNANDEZ J. F. : Extracellular ' in vitro ' evolution of metacyclic trypomastigotes isolated from Trypanosoma cruzi cultures. Rev. Inst. Med. trop. (Sao Paulo), $1978,20,133-138$.

Mazzorti L. : Effects of inoculating small and large numbers of Trypanosoma cruzi into mice. Am. J. Hyg., r940, 31, 86-91.

Menezes H. : Protective effect of an avirulent (cultivated) strain of Trypanosoma cruzi against experimental infection in mice. Rev. Inst. Med. Trop. (Sao Paulo), I968, ro, I-4.

Menezes H. : Essays on immunization of mice with ultraviolet radiated virulent and avirulent culture forms of Trypanosoma cruzi. Rev. Inst. Med. Trop., 1970, 12, 310-319.

MENEZES H. : The protective effect of the epimastigote forms of the PF strain of Trypanosoma cruzi against a virulent homologous infection. Tropenmed. Parasitol., 1976, 27, 418-421.

PHILlips N. R. : Experimental studies on the quantitative transmission of Trypanosoma cruzi : Considerations regarding the standardization of materials. Ann. Trop. Med. Parasitol., 1960, s4, 60-70.

Przzi T. : Immunologia de la Enfermedad de Chagas. Estado actual del problema. Bol. Ofic. Sanit. Panam., I961, $51,450-464$.

RoBerson E. L., HANSON W. L., Chapman W. : Trypanosoma cruzi : Effect of antithymocyte serum in mice and neonatal thymectomy in rats. Exp. Parasitol., 1973, 34, 168-180.

Romanha A. J., Pereira A. A., Chiari E., Kilgour V. : Isoenzyme patterns of cultured Trypanosoma cruzi : changes after prolonged subculture. Comp. Biochem. Physiol., I979, 62B, I39-I 42 .

Rosenberg M. E., Marsden P. D., Petritt L. E. : The infectivity of cultural forms of a Peru strain of Trypanosoma cruzi for $\mathrm{CF}_{1}$ mice and reduviid bugs. Ann. Trop. Med. Parasitol., $1969,63,207-210$.

Silva L. H. P., Nussenzweig V. : Sobre uma cepa de Trypanosoma cruzi altamente virulenta para o camundongo branco. Fol. clin. biol. (Sao Paulo), 1953, 20, 191-207.

Wolf K., Qurmby M. C. : Procedures for subculturing fish cells and propagating fish cell lines. TCA Manual, 1976, 2, 471-474. 